\title{
Red Blood Cells Are a Sink for Interleukin 8, a Leukocyte Chemotaxin
}

\author{
Walter C. Darbonne, ${ }^{\star}$ Glenn C. Rice, ${ }^{*}$ Margorie A. Mohler," Ted Apple, ${ }^{\star}$ Caroline A. Hébert, ${ }^{*}$ \\ Anthony J. Valente," and Joffre B. Baker* \\ Departments of *Cardiovascular Research, ${ }^{\ddagger}$ Cell Biology, and the ${ }^{\S}$ Metabolism Group, Genentech, Inc., South San Francisco, California \\ 94080; "Department of Pathology, University of Texas, Health Science Center, San Antonio, Texas 78284
}

\begin{abstract}
IL-8 (also known as neutrophil-activating peptide 1) is recognized as a potent effector of neutrophil functions. Several different cell types that contact blood, namely $T$ lymphocytes, monocytes, and endothelial cells, secrete this polypeptide following stimulation by cytokines, or lipopolysaccharide. Here we show that when IL-8 is added to blood it rapidly partitions from the plasma fluid to the blood cells and that erythrocytes account for the vast majority of this binding. Analysis of ${ }^{125} \mathrm{I}$ IL-8 binding ([ala-IL-8 $]_{77}$ form) to human red cells indicates a single, $5 \mathrm{nM} K_{\mathrm{d}}$ affinity class of binding sites, present at $\approx 2,000$ per red cell representing $\sim 15 \mathrm{nmol}$ of red cell IL-8 binding sites per liter of blood. These sites are protease sensitive. Their binding of IL-8 is rapidly reversible and does not result in receptor internalization, although bound IL-8 is resistant to extraction by pH 3 buffer at $5^{\circ} \mathrm{C} .{ }^{125} \mathrm{I}-\mathrm{IL}-8$ binding to red cells was not inhibited by epidermal growth factor or interleukin 1, but was inhibited by monocyte chemotactic peptide-1, which is not a neutrophil chemotaxin, but is a member of the same family of polypeptides as IL-8. FACS ${ }^{\circledR}$ analysis of IL-8mediated mobilization of $\mathrm{Ca}^{2+}$ in neutrophils indicates that the IL-8 bound to red cells is incapable of stimulating neutrophils. Thus, red cell absorption of IL-8 may function to limit stimulation of leukocytes by IL-8 released into blood. (J. Clin. Invest. 1991. 88:1362-1369.) Key words: neutrophil-activating peptide $1 \cdot$ monocyte chemotactic peptide $1 \cdot$ erythrocyte $\bullet$ neutrophil - fluorescence activated cell sorter analysis • equilibrium dialysis
\end{abstract}

\section{Introduction}

Interleukin 8 is secreted from activated monocytes (1-3), T lymphocytes (4), fibroblasts (5), and endothelial cells $(6,7)$ and is a potent effector of neutrophils (8) and perhaps also of $T$ lymphocytes (9). This peptide stimulates neutrophil chemotaxis, calcium mobilization (10), morphological polarization (11), and, in the presence of cytochalasin-B, azurophil granule release $(10,11)$. IL-8 also modulates neutrophil:endothelial interaction, causing an up to two- to threefold increase in neutrophil adhesion to resting (and therefore relatively nonadherent) endothelium $(12,13)$, but a $70-90 \%$ decrease in adhesion to cytokine-activated (and therefore highly adherent) endothelium (14). The nature of the effects of IL-8 administered in vivo

Address correspondence and reprint requests to Dr. Joffre B. Baker, Department of Cardiovascular Research, Genentech, Inc., 460 Point San Bruno Boulevard, South San Francisco, CA 94080.

Received for publication 2 April 1991 and in revised form 18 June 1991.

J. Clin. Invest.

(c) The American Society for Clinical Investigation, Inc.

$0021-9738 / 91 / 10 / 1362 / 08 \$ 2.00$

Volume 88, October 1991, 1362-1369 varies dramatically depending on its localization. Thus, whereas intradermally injected IL-8 is a neutrophil chemoattractant $(15,13)$, intravenously injected IL-8 causes rapid transient leukopenia followed by prolonged granulocytosis (16), and also inhibits neutrophil extravasation to intradermal inflammatory sites (17). The latter action may reflect the recently described ability of IL-8 to inhibit adhesion of neutrophils to activated endothelium (14). Repeated intravenous administration of IL-8 causes lung injury similar to that which occurs in adult respiratory distress syndrome (18).

This study demonstrates that when interleukin 8 is introduced into whole blood at concentrations within its biologically active concentration range $(0.1-10 \mathrm{nM})$, this cytokine becomes rapidly and efficiently bound to the red blood cells as a result of an unusual acid-resistant interaction with protein binding sites on the red cell surface. Results presented here also indicate that IL-8 bound to red blood cells is incapable of communicating with neutrophils. Thus, one function of red cell binding sites for IL- 8 could be to limit neutrophil interaction with IL-8 that enters the systemic circulation.

\section{Methods}

Materials. Recombinant human [ala-IL-8 $]_{77}$ and [ser-IL-8 $]_{72}$ were expressed in Escherichia coli and purified as previously described (19). Bovine serum albumin, goat anti-rabbit IgG, platelet factor 4, Sephadex G-25 (100-300 $\mu$ bead size), micro-crystalline cellulose (type 50), and fluorescein isothiocyanate isomer-1 were obtained from Sigma Chemical Co. (St. Louis, MO). Phycoerythrin-conjugated goat antirabbit $\mathrm{Fab}_{2}^{\prime}$ fragments were obtained from CalTag (S. San Francisco, CA). The acetoxymethyl ester of indo-1 was obtained from Molecular Probes Inc. (Eugene, OR). Heparin was obtained from The Upjohn Company (Kalamazoo, MI). Diffusion chambers and diffusion chamber filters were obtained from Nucleopore.

Polyclonal antibody against IL-8 was prepared in rabbits as described by Hébert et al. (19). ${ }^{125} \mathrm{I}$-[ala-IL-8] ${ }_{77}$ (specific activity ranging between $2-4 \times 10^{7} \mathrm{cpm} / \mu \mathrm{g}$ ) was prepared and radioimmunoassay for IL-8 (maximal sensitivity $\approx 50 \mathrm{pM}$ ) performed as previously described (19). Enzyme-linked immunosorbant assay for tissue-type plasminogen activator was carried out as described by Ramakrishnan et al. (20).

Isolation of blood cells. Neutrophils were isolated as described by Wheeler et al. (21). Erythrocytes were isolated by a modification of the procedures of Nakao et al. (22) and Beutler et al. (23). Briefly, fresh whole blood was drawn into a heparinized syringe $(10 \mathrm{U}$ heparin $/ \mathrm{ml}$ whole blood) from healthy human volunteers or animals. Different blood donors were used for replicate experiments. Whole blood was then passed over two tandem 20-ml polypropylene syringes that were packed with microcrystalline cellulose/Sephadex G25 (in 3:1 ratio) and that contained cotton filters at their outlets. The columns were washed with 5-10 vol of $0.154 \mathrm{M} \mathrm{NaCl}$. The erythrocyte-containing eluate was then washed thrice by centrifugation at $1,000 \mathrm{~g}$ and resuspension in

1. Abbreviations used in this paper: [ala-IL-8 $]_{77}, 77$ amino acid form of IL-8 with $\mathrm{NH}_{2}$-terminal alanine; [ser-IL-8] $]_{72}, 72$ amino acid form of IL-8 with $\mathrm{NH}_{2}$-terminal serine; $\mathrm{MCP}$, monocyte chemotactic protein. 
PBS containing $1 \%$ BSA. Blood cell counts were performed on a Baker 9000 hematology analyzer (Baker Instrument Co., Allentown, PA) to check for removal of white blood cells and platelets. It was determined that it was occasionally necessary to have the second column in series in order to achieve removal of greater than $99 \%$ of the leukocytes. Erythrocyte ghosts were prepared from outdated red blood cells as described by Hanahan and Ekholm (24).

Measurement of $I L-8$ binding. Freshly isolated erythrocytes were diluted with binding medium (PBS containing $1 \%$ BSA) to achieve the desired cell concentrations. $250 \mu$ l of the washed cells were then sedimented for $1 \mathrm{~min}$ at $13,000 \mathrm{~g}$ in a microfuge. $125 \mu \mathrm{l}$ of the supernatant was replaced with binding medium containing ${ }^{125} \mathrm{I}-\mathrm{IL}-8$ plus or minus nonlabeled IL-8 as indicated. The cells were resuspended and incubated for $15 \mathrm{~min}$ at $37^{\circ} \mathrm{C}$, unless otherwise indicated, and layered atop $0.5 \mathrm{ml}$ of binding medium containing $20 \%$ sucrose. The cells were sedimented by centrifugation for $3 \mathrm{~min}$ in a microcentrifuge at 13,000 $g$, and the radioactivity in the cell pellet and supernatant quantified in a Packard Minaxi 5000 series gamma counter (Packard Instruments Co., Inc., Downers Grove, IL). In the case of red cell ghosts, the binding assay was modified as follows. At the end of the binding incubation the contents of the binding incubation mixture were quickly diluted with 5 vol of PBS, and the ghosts were pelleted by $25 \mathrm{~min}$ centrifugation at $16,000 \mathrm{~g}$.

The fraction of ${ }^{125}$ I-IL-8 molecules that had specific binding activity was determined by carrying out a 15-min incubation of red cells with $\approx 10,000 \mathrm{cpm}$ of the radiolabeled ligand plus or minus $1 \mu \mathrm{M}$ nonlabeled IL-8. The "bindable" fraction was estimated from the $Y$ axis intercept of a plot of the inverse of specifically bound radioactivity (on the $\mathrm{Y}$ axis) versus the inverse of cell concentration (on the $\mathrm{X}$ axis), as recently described by Besemer et al. (25).

FACS analysis methods. IL-8 was fluoresceinated by incubation with fluorescein isothiocyanate Isomer-I (FITC) in $0.5 \mathrm{M} \mathrm{NaHCO}_{3}$ at $\mathrm{pH} 9.0$ at a ratio of $1: 10 \mathrm{FITC} / \mathrm{IL}-8(\mathrm{wt} / \mathrm{wt})$. The reaction proceeded for $90 \mathrm{~min}$ at $20^{\circ} \mathrm{C}$. The solution was neutralized and BSA at $0.04 \%$ final concentration was added. Free FITC was removed by centrifugation through a Centricon 3 unit (Amicon Division of W. R. Grace and Co., Danvers, MA). The FITC/protein ratio was $\approx 2$. Immediately, $2 \times 10^{5}$ red cells were stained with FITC-IL-8 by coincubation for $1 \mathrm{~h}$ at $5^{\circ} \mathrm{C}$ in PBS containing $2 \%$ fetal calf serum. The cells were washed thrice and analyzed on a Coulter Elite flow cytometer (Coulter Electronics Inc., Hialeah, FL), using 488-nm laser excitation $(15 \mathrm{~mW})$ and emission detected using a $525-\mathrm{nm}( \pm 20 \mathrm{~nm})$ band pass filter. Some samples were incubated simultaneously with a 100 -fold excess of unlabeled IL-8, except the 100 - and $250-\mathrm{nM}$ points which were incubated with $5 \mu \mathrm{M}$ unlabeled IL-8. For indirect measurement of IL-8 binding to red blood cells, the cells were incubated with IL-8 for $1 \mathrm{~h}$, and then incubated with a 1:200 dilution of the rabbit anti-IL-8 antisera. The cells were then incubated with phycoerythrin-conjugated goat anti-rabbit Fab'2 and analyzed by FACS using a $575-\mathrm{nm}( \pm 25 \mathrm{~nm})$ band pass filter. All incubations were performed on ice and the cells were washed three times between staining steps with PBS containing 2\% fetal calf serum. Samples were analyzed by calculation of the peak mean fluorescence intensity normalized to the control (autofluorescence sample for FITCIL-8 staining; polyclonal and anti-rabbit phycoerythrin antibody stained sample for indirect staining).

Calcium mobilization was measured by loading neutrophils (1 $\times 10^{6} / \mathrm{ml}$ ) with $10 \mu \mathrm{M}$ indo-1 acetoxymethyl ester (26) for $15 \mathrm{~min}$ at $37^{\circ} \mathrm{C}$ in RPMI medium. The cells were analyzed by FACS using 200 $\mathrm{mW}$ UV excitation (351.1-363.8 $\mathrm{nm}$ ) with fluorescence emission collected as a ratio of $405: 525 \mathrm{~nm}$ as described by June and Rabinovitch (27).

\section{Results}

Absorption of IL-8 by red blood cells. IL-8 is found in several different forms. The most common, [ala-IL-8] $]_{77}$ and [ser-IL$8]_{72}$, are distinguished solely by the 5 amino acid extension at the amino-terminus of the former. Qualitatively, their activities are similar, with [ser-IL-8 $]_{72}$ exhibiting somewhat greater activity (19). Unless noted otherwise, herein, the term IL-8 will refer to [ala-IL-8 $]_{77}$, which is the form of IL-8 secreted by endothelial cells (14) and the IL-8 form used for most of the following experiments. Because a number of signal-transmitting polypeptides have humoral binding proteins $(28,29)$, we sought to determine whether blood contained an IL-8-binding protein by adding ${ }^{125} \mathrm{I}-\mathrm{IL}-8$ to plasma and monitoring its size by gel filtration. This experiment did not suggest that IL-8 became absorbed to a soluble binding protein (M. Mohler, unpublished data). However, as shown by the radioimmunoassay data in Table I, when IL-8 in the nanomolar concentration range was added to human whole blood it became depleted from the plasma. Thus, whereas $73 \%$ was lost when IL-8 was added at 2 $\mathrm{nM}$, little or none was lost when IL-8 was added at $\approx 100 \mathrm{nM}$. In contrast, IL-8 added to plasma was detectable at roughly undiminished concentration at all concentrations examined. Direct evidence that the IL- 8 was being absorbed by the blood cells was obtained by incubating $10 \mathrm{nM}{ }^{125} \mathrm{I}-\mathrm{IL}-8$ in human whole blood for $10 \mathrm{~min}$ and then counting the radioactivity associated with cells and plasma supernatant. About $55 \%$ of the radioactivity rapidly redistributed from the plasma to the cells (Fig. 1).

Repeated low speed $(600 \mathrm{~g})$ centrifugation and removal of the buffy coat did not diminish the ${ }^{125} \mathrm{I}-\mathrm{IL}-8$ binding capacity of the blood cells (data not shown), indicating that the binding activity was a property of the red cells. Therefore, red cells were

Table I. Disappearance of Soluble IL-8 from Whole Blood*

\begin{tabular}{lrrr}
\hline \multicolumn{1}{c}{ Condition } & IL-8 added & IL-8 recovered & Percentage recovered \\
\hline & & $n M$ & \\
Addition to whole & 2 & 0.54 & 27 \\
blood & 8 & 2.98 & 37 \\
& 32 & 12.47 & 39 \\
& 128 & 136.64 & 107 \\
& 512 & 507.65 & 99 \\
Addition to & 2,050 & $2,978.43$ & 145 \\
plasma & 2 & 1.88 & 94 \\
& 8 & 5.79 & 72 \\
& 32 & 26.35 & 82 \\
& 128 & 144.07 & 113 \\
& 512 & 515.10 & 101 \\
& 2,050 & $2,327.90$ & 114 \\
\hline
\end{tabular}

* Plasma was derived from freshly drawn heparinized $(10 \mathrm{U} / \mathrm{ml})$ whole blood by twice sedimenting the blood cells in a centrifuge at $1000 \mathrm{~g}$ for $4 \mathrm{~min}$. The cells from $250-\mu \mathrm{l}$ aliquots of whole blood were sedimented by centrifugation for $1 \mathrm{~min}$ in a microfuge, and $125 \mu \mathrm{l}$ of the plasma supernatant was removed. In duplicate, $125 \mu \mathrm{l}$ of plasma spiked with IL-8, to generate the indicated IL-8 concentrations, was then added back to the cell pellets and to $125-\mu \mathrm{l}$ plasma aliquots. The cells were resuspended and then incubated with the plasma dilutions of IL-8 for $15 \mathrm{~min}$ at $37^{\circ} \mathrm{C}$. The cells were then sedimented and soluble IL-8 was quantified in the resulting cell plasma supernatants and plasma dilutions by radioimmunoassay (19) (maximum sensitivity $=50 \mathrm{pM}$ ) using standards diluted in plasma derived from the same blood. The measured concentrations of IL-8 added to plasma generally conform to the theoretical concentrations based on the known amounts of IL-8 added. 


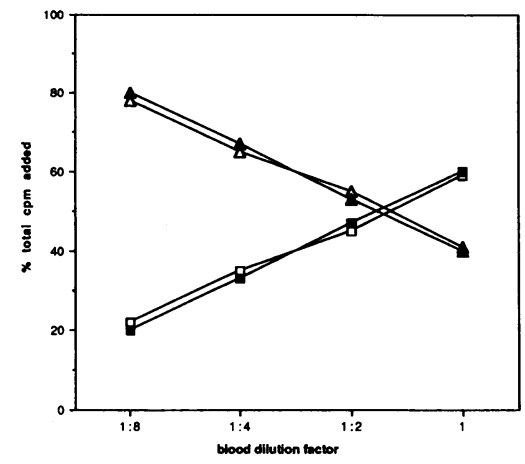

Figure 1. Binding of ${ }^{125}$ I-IL-8 to unfractionated blood cells and isolated erythrocytes. Purified red blood cells and unfractionated whole blood cells, both in $1 \%$ BSA/PBS, were diluted to $3.7 \times 10^{9}$ cells $/ \mathrm{ml}$, as determined with a Coulter Counter (Coulter Electronics Inc.). These (" $1 \mathrm{x}$ ") preparations, and the

indicated dilutions thereof, were incubated with $10 \mathrm{nM}{ }^{125} \mathrm{I}-\mathrm{IL}-8$ for $20 \mathrm{~min}$ at $37^{\circ} \mathrm{C}$ and the cell-associated radioactivity measured. Closed and open symbols represent experiments with isolated red blood cells, or infractionated blood cells, respectively. Squares represent fraction of radiolabeled ligand bound to cells. Triangles represent fraction of radiolabeled ligand not bound to cells.

highly purified and their ${ }^{125}$ I-IL-8 binding activity was compared with that of unfractionated blood cells. As shown in Fig. 1 , purified human red cells at their concentration in whole blood $\left(\approx 4 \times 10^{9} / \mathrm{ml}\right)$ bound $\sim 55 \%$ of ${ }^{125} \mathrm{I}-\mathrm{IL}-8$ added at 10 $\mathrm{nM}$. This percentage decreased linearly with serial dilution of the cells, down to $\sim 20 \%$ at a 1:8 cell dilution. The ${ }^{125} \mathrm{I}-\mathrm{IL}-8$ binding capacities of unfractionated blood cells and of isolated red cells were equivalent. Thus, the red blood cells were responsible for the extensive binding of ${ }^{125} \mathrm{I}-\mathrm{IL}-8$ by blood cells.

As predicted by radioimmunoassay of IL- 8 added to whole blood (Table I), ${ }^{125}$ I-IL-8 binding to red cells was saturable (Fig. 2). At ${ }^{125} \mathrm{I}-\mathrm{IL}-8$ concentrations up to $\sim 1 \mathrm{nM}, \sim 70 \%$ of the input ligand became absorbed to the cells, whereas at $100 \mathrm{nM}$ ${ }^{125}$ I-IL-8 this fraction had decreased to $\sim 10 \%$ (Fig. 2, closed bars). Furthermore, excess nonlabeled IL-8 inhibited the binding of ${ }^{125} \mathrm{I}-\mathrm{IL}-8$ (see below). These results indicated that red cells contained specific binding sites for IL-8. About $50-70 \%$ of the radioiodinated IL-8 molecules (depending on the preparation) had the capacity to bind to red cell specific binding sites (see Methods). Besemer et al. (25) made a similar observation with respect to binding of their radioiodinated IL-8 preparations to neutrophil receptors. The cross-hatched bars in Fig. 2 show

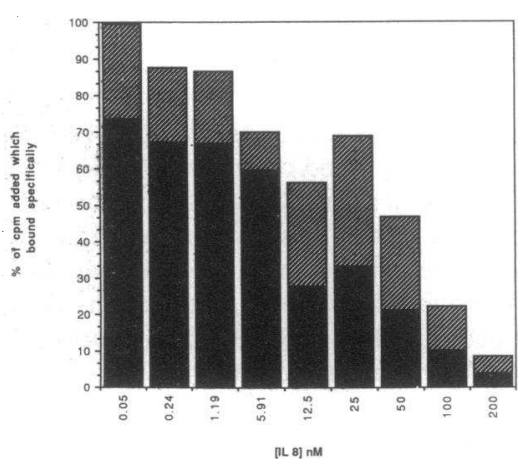

Figure 2. Absorption of ${ }^{125}$ I-IL- 8 by erythrocytes. Red cells at 4.0 $\times 10^{9} / \mathrm{ml}$ were incubated with ${ }^{125} \mathrm{I}-\mathrm{IL}-8$ at the indicated concentrations with or without $1 \mu \mathrm{M}$ nonlabeled IL-8, for $15 \mathrm{~min}$ at $37^{\circ} \mathrm{C}$. The percentage of radioactivity that was specifically bound is shown by the closed bars. The levels indicated by the cross-hatched bars show the percentage of "bindable" ${ }^{125}$ I-IL-8 that was specifically bound, derived by subtracting the fraction of ligand that was found (see protocol in Methods) to be incapable of binding. This graph represents data from two experiments. that the fraction of "bindable" ${ }^{125}$ I-IL-8 absorbed by red cells exceeded $80 \%$ at ${ }^{125} \mathrm{I}-\mathrm{IL}-8$ concentrations below $\sim 1 \mathrm{nM}$. It is noteworthy that red cell absorption of IL-8 had its maximal impact on soluble IL-8 levels in the IL-8 concentration range over which neutrophil responses have been shown to occur and be dose dependent (reference 8 , and Fig. 8 below).

As an independent test for red blood cell absorption of IL-8, we examined the influence of red cells on the equilibration of IL-8 across the compartments of a diffusion chamber. Red blood cells at $4 \times 10^{9} / \mathrm{ml}$ were placed in the lower compartment, which was separated from the upper compartment by a filter containing pores with a $5 \mu \mathrm{m}$ diameter. IL- 8 was added to either compartment, the chambers were incubated overnight on a rotary shaker at $23^{\circ} \mathrm{C}$, and the amount of $\mathrm{IL}-8$ in the buffer fluid of the two compartments was determined by radioimmunoassay. Control experiments with ${ }^{3} \mathrm{H}$-inulin indicated that the red cells did not pose a significant barrier to diffusion, and that the concentration of this inert molecule approached equilibrium (Table II). As shown in Table II, when IL-8 was added to the red cell side no detectable IL-8 antigen escaped to the opposite compartment or was found in the buffer in the red cell compartment. Red cells also caused depletion of IL-8 when the IL-8 was added to the compartment opposite to the red cells. The amount of depletion of IL-8 antigen in this case, although not complete, was also large. Data similar to those given in Table II were obtained in all (three) replicate experiments. Red cells did not act as a sink for proteins in general in these experiments because their presence did not influence the diffusion of tissue type plasminogen activator across the diffusion chambers (data not shown).

Properties of the red cell $I L-8$ interaction. Specific binding of ${ }^{125} \mathrm{I}-\mathrm{IL}-8$ reached steady-state at the earliest time points that could be taken (see Fig. 6 below). Fig. 3 illustrates that this interaction was also rapidly reversible. ${ }^{125} \mathrm{I}-\mathrm{IL}-8$ was incubated with red cells for $15 \mathrm{~min}$ at $37^{\circ} \mathrm{C}$, and then the incubation mixture was diluted 100 -fold. At various times the cells were sedimented and their specifically-bound ${ }^{125}$ I-IL-8 was measured. As shown, virtually all of the specifically-bound ligand had dissociated at the earliest (" $t_{0}$ ") time point after the dilution. Because the centrifugation and manipulations at each time point consumed about $5 \mathrm{~min}$, the experimental protocol did not allow measurement of the $t_{1 / 2}$ for dissociation of ${ }^{125} \mathrm{I}-\mathrm{IL}$ 8. Nevertheless, the data indicate that this is considerably less than $5 \mathrm{~min}$.

About $70 \%$ of the total binding of $0.1 \mathrm{nM}^{125} \mathrm{I}-\mathrm{IL}-8$ was eliminated in the presence of $1 \mu \mathrm{M}$ nonlabeled IL-8 (Fig. 4). In contrast, unrelated polypeptides, epidermal growth factor and interleukin 1 , at $1 \mu \mathrm{M}$ concentrations did not detectably influence ${ }^{125} \mathrm{I}-\mathrm{IL}-8$ binding (data not shown). Analysis of the ligand dose dependence of steady-state binding using the LIGAND program (30) indicated that red cells display a single affinity class of ${ }^{125} \mathrm{I}-\mathrm{IL}-8$ binding sites, at $1,500-3,000$ per cell with a $\approx 5 \mathrm{nM} K_{\mathrm{d}}$ (Fig. 4). This translates to about $15 \mathrm{nmol}$ of red cell binding sites per liter of whole blood.

Independent analysis of IL-8 binding sites on red cells was carried out using a FACS to examine the interaction of FITClabeled IL-8 with red cells. As shown in Fig. $5 A$, this IL-8 derivative bound to red cells with $\mathrm{a} \approx 10 \mathrm{nM} K_{\mathrm{d}}$, and the binding was inhibited in the presence of excess native IL-8. In addition, native IL-8 was incubated with red cells, and binding of the ligand was detected indirectly (Fig. 5 E). Although this 
Table II. Diffusion of IL-8 in the Presence and Absence of Erythrocytes

\begin{tabular}{|c|c|c|c|c|c|c|}
\hline Condition & $\begin{array}{l}\text { Initial } \\
\text { condition }\end{array}$ & Chamber side & $\begin{array}{l}\text { Final soluble } \\
\text { [IL-8] }\end{array}$ & Range & $\begin{array}{l}\text { Total soluble } \\
\text { IL-8 recovered }\end{array}$ & $\begin{array}{l}\text { [3H] Inulin ratio } \\
\text { (top/bottom) }\end{array}$ \\
\hline & & & $n M$ & & $\%$ & \\
\hline \multirow[t]{2}{*}{1} & buffer & Top & LTS & $(---)$ & 0 & 1.04 \\
\hline & RBCs +0.5 nM IL-8 & Bottom & LTS & $(---)$ & & \\
\hline \multirow[t]{2}{*}{2} & buffer & Top & 0.17 & 0 & 68 & 0.77 \\
\hline & $0.5 \mathrm{nM}$ IL-8 & Bottom & 0.17 & 0.02 & & \\
\hline \multirow[t]{2}{*}{3} & $0.5 \mathrm{nM}$ IL-8 & Top & 0.06 & 0.04 & 12 & 0.99 \\
\hline & RBCs & Bottom & LTS & $(---)$ & & \\
\hline \multirow[t]{2}{*}{4} & $0.5 \mathrm{nM}$ IL-8 & Top & 0.185 & 0.03 & 66 & 1.02 \\
\hline & buffer & Bottom & 0.145 & 0.09 & & \\
\hline
\end{tabular}

* Red blood cells were isolated from freshly drawn heparinized $(10 \mathrm{U} / \mathrm{ml})$ human whole blood, and resuspended to $5 \times 10^{9}$ cells $/ \mathrm{ml}$ in PBS buffer containing $1 \%$ BSA. $200 \mu \mathrm{l}$ of the various mixtures indicated were added to the bottom of a chemotactic chamber (Nucleopore Corp., Pleasanton, CA). After securing a $5.0 \mu \mathrm{m}$ pore diameter filter over the bottom chamber, $200 \mu$ l of the indicated mixtures were added to the top chamber (on the filter). Duplicate chemotactic chambers were set up for each condition. In the first condition indicated, the red blood cells were preincubated with $0.5 \mathrm{nM}$ IL- 8 at $37^{\circ} \mathrm{C}$ for $15 \mathrm{~min}$ before the direct addition of the mixture to the bottom chamber. The top of the chemotactic chamber was then covered with parafilm, and incubated on a rotary shaker at room temperature for $24 \mathrm{~h}$. The contents of each chamber side were then collected. The red blood cells in the samples from conditions 1 and 3 were sedimented by a 3-min centrifugation in a microfuge. Radioimmunoassay was used to determine the concentration of IL-8 in the resulting supernatants and chamber solutions. LTS, less than standard; $<50 \mathrm{pM}$.

indirect method does not allow for subtraction of nonspecific binding, it is noteworthy that the slope of the binding versus concentration curve was substantially steeper at ligand concentrations below $\approx 15 \mathrm{nM}$ than at higher ligand concentrations, consistent with IL-8 binding to a saturable site on the cells that had approximately the $K_{d}$ predicted by our other experiments.

Resistance of cell-bound polypeptide ligands to extraction by $\mathrm{pH}$ 2.5-3.0 buffer on ice is a commonly used criterion for internalized ligand because, in general, noncovalent protein: protein interactions are disrupted at this $\mathrm{pH}(31,32)$. Red cells were incubated with ${ }^{125} \mathrm{I}-\mathrm{IL}-8$ for various times at $37^{\circ} \mathrm{C}$ and then incubated in $0.1 \mathrm{M}$ glycine buffer ( $\mathrm{pH} 3$ ) for $3 \mathrm{~min}$ on ice. As shown in Fig. 6, regardless of the length of time of incubation of red cells with ${ }^{125} \mathrm{I}-\mathrm{IL}-8$ (up to $90 \mathrm{~min}$ ), little ( $\approx 20 \%$ ) of the bound ${ }^{125} \mathrm{I}-\mathrm{IL}-8$ dissociated from the cells upon $\mathrm{pH} 3$ treatment at $5^{\circ} \mathrm{C}$. This at first suggested that the ligand had been internalized. However, it was also determined that $>90 \%$ of

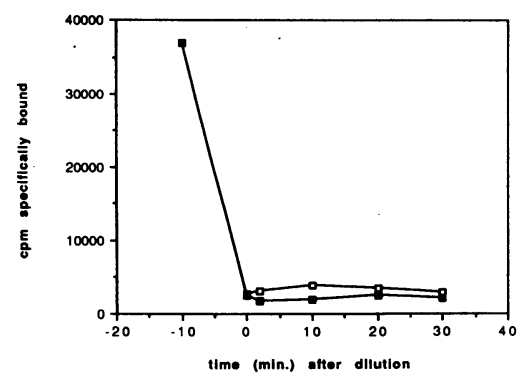

Figure 3. Time course of dissociation of specifically bound IL-8. Red blood cells at $5.1 \times 10^{9}$ cells/ml were incubated with $5 \mathrm{nM}{ }^{125} \mathrm{I}-\mathrm{IL}-8$ with or without $1 \mu \mathrm{M}$ nonlabeled IL-8 for $15 \mathrm{~min}$ at $37^{\circ} \mathrm{C}$. An aliquot of the suspension was removed to measure cellassociated radioactivity and the rest was diluted 100 -fold in $1 \%$ BSA/PBS. The mixtures were then incubated at $4^{\circ}$ or $37^{\circ} \mathrm{C}$, and at the indicated time points aliquots were taken for measurement of cell-associated radioactivity. Shown is the radioactivity specifically bound to $6 \times 10^{8}$ cells. Open square, $37^{\circ} \mathrm{C}$; closed square, $4^{\circ} \mathrm{C}$. This figure is representative of four experiments.

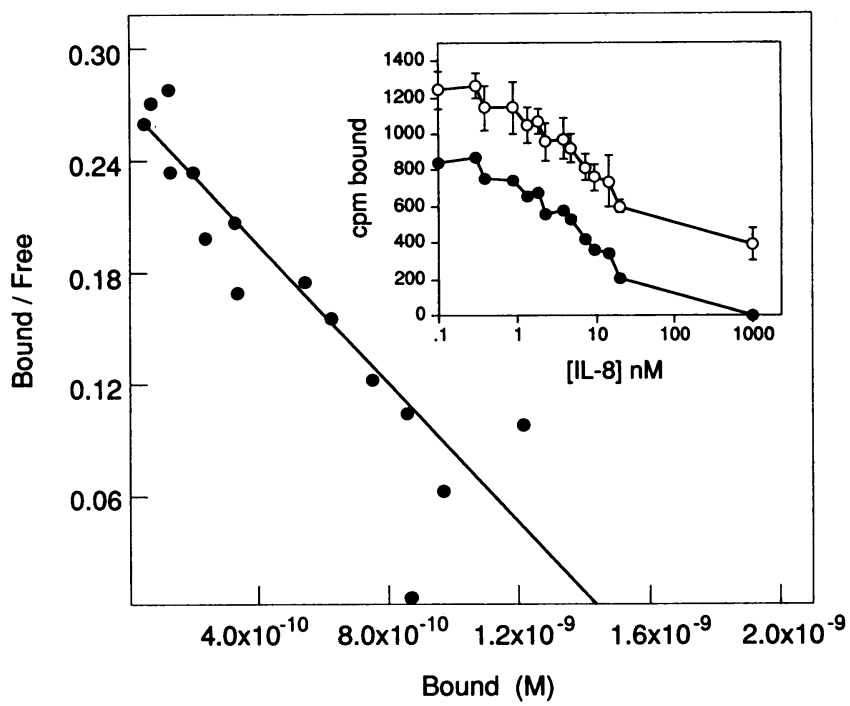

Figure 4. Analysis of ${ }^{125} \mathrm{I}$-IL-8 binding to human red blood cells. Erythrocytes $\left(1.22 \times 10^{8}\right.$ cells $/ 250-\mu 1$ aliquot) were sedimented by a 1 -min centrifugation in a microfuge. $125 \mu$ of the resulting supernatants were replaced with $125 \mu \mathrm{l}$ mixtures of $0.1 \mathrm{nM}^{125} \mathrm{I}-\mathrm{IL}-8$ and increasing concentrations of nonlabeled IL-8 (two-fold dilutions from $0.2-40 \mathrm{nM}$, and $1,000 \mathrm{nM}$ ) in $1 \% \mathrm{BSA} / \mathrm{PBS}$, each point in quintuplicate. The cells were resuspended and incubated at $37^{\circ} \mathrm{C}$ for $20 \mathrm{~min}$. The cell suspensions were each layered onto a $0.5 \mathrm{ml} 20 \%$ sucrose/ $0.1 \% \mathrm{BSA} / \mathrm{PBS}$ cushion, the cells sedimented and the radioactivity in the cell pellets and supernatants quantified. The LIGAND program of Munson and Rodbard (30) was then used to estimate binding site number and affinity and develop a Scatchard plot of the data. The inset shows the binding data plotted as a function of the logarithm of IL-8 concentration (nM), with open and closed symbols showing total and specific binding, respectively. This analysis is representative of four separate competition binding experiments. The error bars represent SD of ${ }^{125} \mathrm{I}-\mathrm{IL}-8$ total binding to red cells in the presence of the respective concentration of cold ligand. 

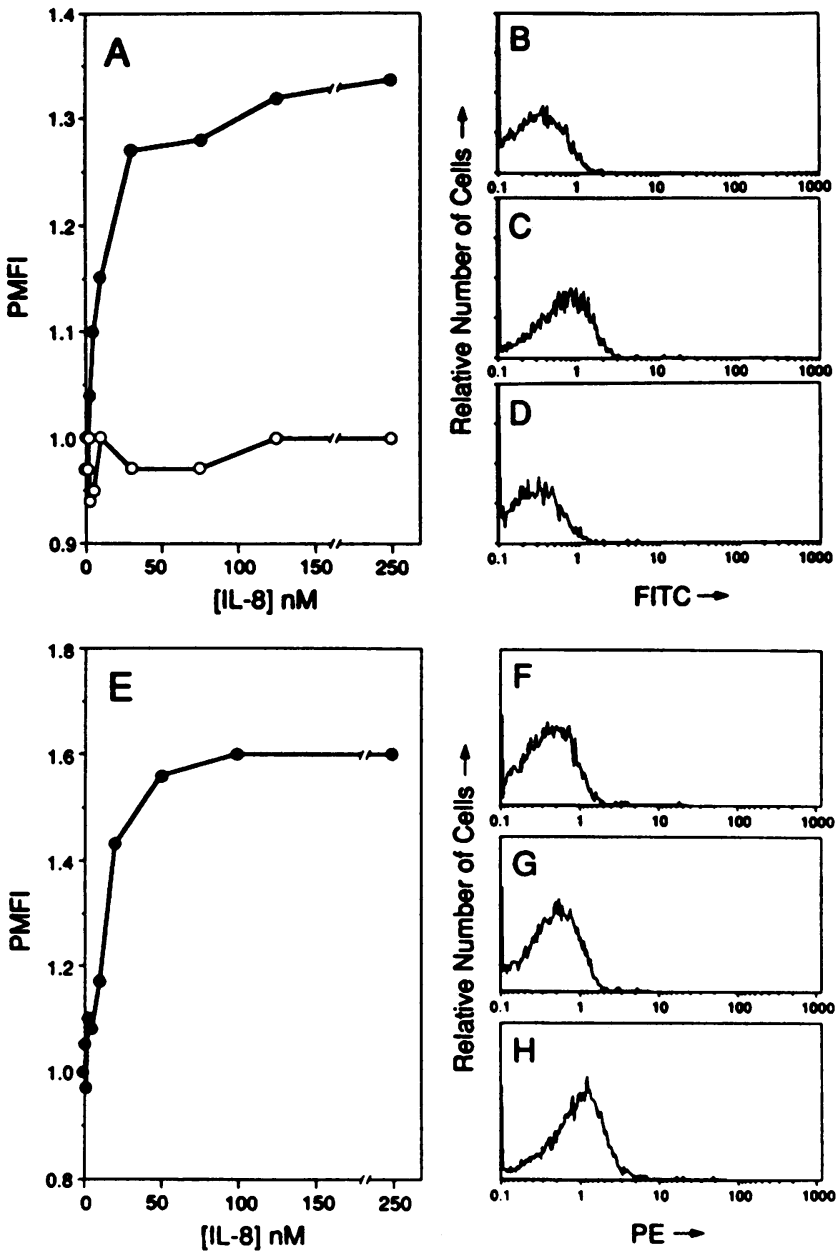

Figure 5. Flow cytometric analysis of binding of IL-8 to human red blood cells. $(A)$ Binding of FITC-IL-8 to cells with (open symbols) or without (closed symbols) addition of 100 -fold excess of unconjugated IL-8. Plotted is the peak mean fluorescence intensity (PMFI) normalized to the control. Representative fluorescence histograms of FITC-IL-8 binding are shown to the right of the graph, illustrating autofluorescence $(B) ; 75 \mathrm{nM}$ FITC-IL-8 $(C)$; and $75 \mathrm{nM}$ FITC-IL-8 plus $7.5 \mu \mathrm{M}$ unconjugated IL-8. $E-H$ display measurement of IL-8 binding to red cells using an indirect staining approach. Cells were stained with various concentrations of IL-8, followed by polyclonal sera against IL-8 $(D)$, followed by goat anti-rabbit phycoerythrin-conjugated $\mathrm{Fab}_{2}^{\prime}$ and analyzed by FACS $(E)$. Representative histograms are shown to the right: $F$, anti-rabbit phycoerythrin-conjugated antibody only; $G$, polyclonal sera plus anti-rabbit phycoerythrin-conjugated antibody; $H$, IL-8 plus polyclonal sera plus anti-rabbit phycoerythrin-conjugated antibody. Data from direct and indirect FACS analysis is representative of three experiments for each method.

the bound ligand rapidly dissociated from the cells upon the addition of excess IL-8 (0.5 $\mu \mathrm{M}$; Fig. 6). Thus, ${ }^{125} \mathrm{I}-\mathrm{IL}-8$ became associated with the red cell surface in an unusual pH 3-resistant interaction, and did not become internalized. Other experiments demonstrated that ${ }^{125} \mathrm{I}-\mathrm{IL}-8$ did not become internalized by red cells even after incubation overnight at $37^{\circ} \mathrm{C}$, as virtually all of the specifically bound ${ }^{125} \mathrm{I}-\mathrm{IL}-8$ was displaced by addition of excess nonlabeled IL-8.

In contrast to the resistance of red cell-bound ${ }^{125} \mathrm{I}-\mathrm{IL}-8$ to extraction by $\mathrm{pH} 3$ buffer in the cold, this bound ligand was rapidly extracted by the same $\mathrm{pH} 3$ buffer at $37^{\circ} \mathrm{C}$ (data not

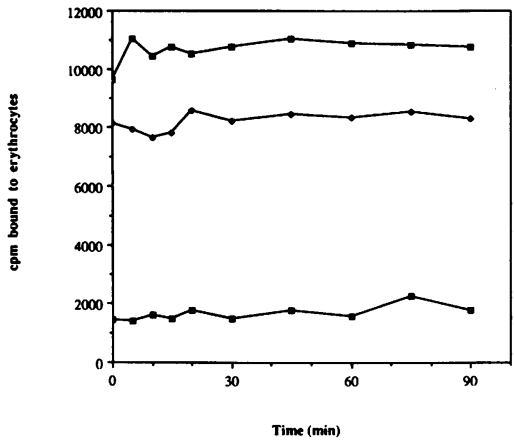

Figure 6. Extraction of IL-8 bound to red blood cells. Red blood cells at $4.85 \times 10^{9}$ cells $/ \mathrm{ml}$ were incubated with 10 $\mathrm{nM}^{125} \mathrm{I}-\mathrm{IL}-8$ at $37^{\circ} \mathrm{C}$ At the time points indicated, three 250- $\mu$ laliquots were removed and treated as follows: the cells were sedimented through a sucrose cushion and the radioactivity in the cell pellets

counted (open square). The cells were sedimented by centrifugation in a microfuge for $1 \mathrm{~min}$. $125 \mu \mathrm{l}$ of the supernatant was replaced with $0.1 \mathrm{M}$ glycine/0.154 M NaCl buffer at $\mathrm{pH}$ 3.0. The cells were resuspended and incubated at $4^{\circ} \mathrm{C}$ for $3 \mathrm{~min}$. The cell suspension was then sedimented through a sucrose cushion, and the radioactivity in the resulting supernatant and cell pellet was quantified (closed diamond). The cells were sedimented by centrifugation in a microfuge for $1 \mathrm{~min}$. $125 \mu \mathrm{l}$ of the supernatant was replaced with buffer containing nonlabeled IL-8 at a final concentration of $5 \mu \mathrm{M}$. The cells were resuspended and incubated at $4^{\circ} \mathrm{C}$ for $3 \mathrm{~min}$. The cell suspension was then sedimented through a sucrose cushion and the radioactivity in the cell pellet was quantified (closed square). This figure is representative of five experiments.

presented). At this temperature the acidic buffer extracted the bound ${ }^{125} \mathrm{I}-\mathrm{IL}-8$ as efficiently as did excess nonlabeled IL-8. It is noteworthy that the opposite effect of temperature on $\mathrm{pH} 3$ extraction of neutrophil-bound ${ }^{125} \mathrm{I}-\mathrm{IL}-8$ (sensitivity at $4^{\circ} \mathrm{C}$ and resistance at $37^{\circ} \mathrm{C}$ ) has been reported (25). The possibility that the red cell binding sites for IL-8 were located on the plasma membrane was supported by the finding that red cell ghosts specifically bound ${ }^{125}$ I-IL-8 (data not shown; see Methods for experimental details).

Red cell binding of ${ }^{125}$ I-IL-8 was not significantly altered by preincubation of the cells with high levels of trypsin $(100 \mu \mathrm{M})$. However, preincubation of the cells with similar amounts of chymotrypsin or pronase reduced their specific binding of ${ }^{125} \mathrm{I}$ IL- 8 by 50 and $100 \%$, respectively (Fig. $7 A$ ). These treatments did not cause detectable hemolysis. The loss of binding was not caused by digestion and inactivation of the ${ }^{125} \mathrm{I}-\mathrm{IL}-8$ ligand by residual protease that did not wash off of the red cells after their protease treatment. SDS polyacrylamide gel electrophoresis (carried out in the presence of dithiothreitol) and autoradiography indicated that the ${ }^{125} \mathrm{I}-\mathrm{IL}-8$ ligand was intact after the binding incubations (data not presented). Moreover, the recovered ligand bound to red cells that had not been preincubated with protease (Fig. 7 B). These results thus suggest that the red cell binding site for $\mathrm{IL}-8$ is a protein.

IL-8 bound to red cells is not accessible to neutrophils. Because neutrophils are recognized as a primary target of IL-8 action (8), we designed an experiment to determine whether IL-8 that was bound to red cells could stimulate neutrophils. The previously described rise in cytosolic free calcium that occurs as an early response of neutrophils to IL-8 (11) was chosen as an indicator of IL-8 signal transmission. Neutrophils were loaded with the calcium-sensitive dye, indo-1, incubated with IL-8, and calcium ion levels measured in a fluorescence-activated cell sorter. Fig. 8 shows the recording of calcium mobilization in neutrophils induced by IL-8. Dose-response curves 

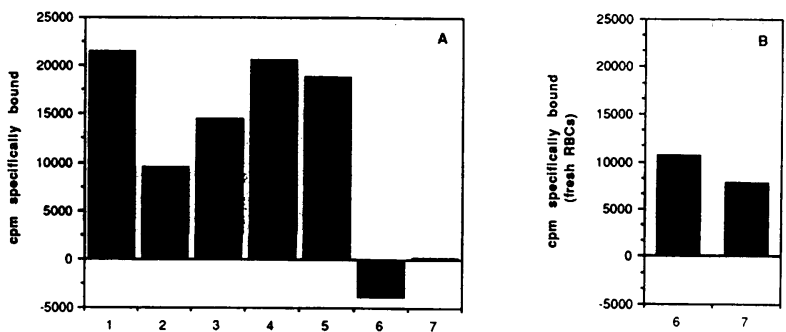

Figure 7. IL-8 binding to erythrocytes pretreated with proteases. $(A)$ Erythrocytes at $3.5 \times 10^{9}$ cells $/ \mathrm{ml}$ were incubated with the proteases indicated below for $30 \mathrm{~min}$ at $37^{\circ} \mathrm{C}$. A subset of these cells underwent a second protease incubation for a further $30 \mathrm{~min}$ by replacing the protease-containing supernatant with fresh solution of $200 \mu \mathrm{g} / \mathrm{ml}$ protease. The protease-treated cell suspensions were then washed by repeated sedimentation and resuspension, diluted tenfold in PBS containing $1 \mathrm{mM}$ PMSF, $3 \mathrm{mM}$ EDTA, $100 \mu \mathrm{g} / \mathrm{ml}$ aprotinin, and $10 \%$ fetal calf serum. The treated red blood cells were then diluted tenfold and washed twice in $1 \%$ BSA/PBS before resuspension in 5 $\mathrm{nM}^{125} \mathrm{I}-\mathrm{IL}-8$ at the original $(250 \mu \mathrm{l})$ volume. The cells were incubated at $37^{\circ} \mathrm{C}$ for $15 \mathrm{~min}$, sedimented, and the radioactivity in the cell pellet quantified. (B) $100 \mu \mathrm{l}$ of the ${ }^{125} \mathrm{I}-\mathrm{IL}-8$-containing supernatants $(80 \%$ of volume) from the cells that had been incubated with pronase were then used to resuspend $100 \mu l$ of fresh red blood cells that had been sedimented by centrifugation. The cells were then incubated for 15 min at $37^{\circ} \mathrm{C}$, sedimented, and the radioactivity in the cell pellet quantified. The data represents reproducible data attained in four experiments. Key to protease treatment conditions: 1, buffer control; 2 , chymotrypsin (two incubations); 3 , chymotrypsin (one incubation); 4, trypsin (two incubations); 5 , trypsin (one incubation); 6 , pronase (two incubations); 7, pronase (one incubation).

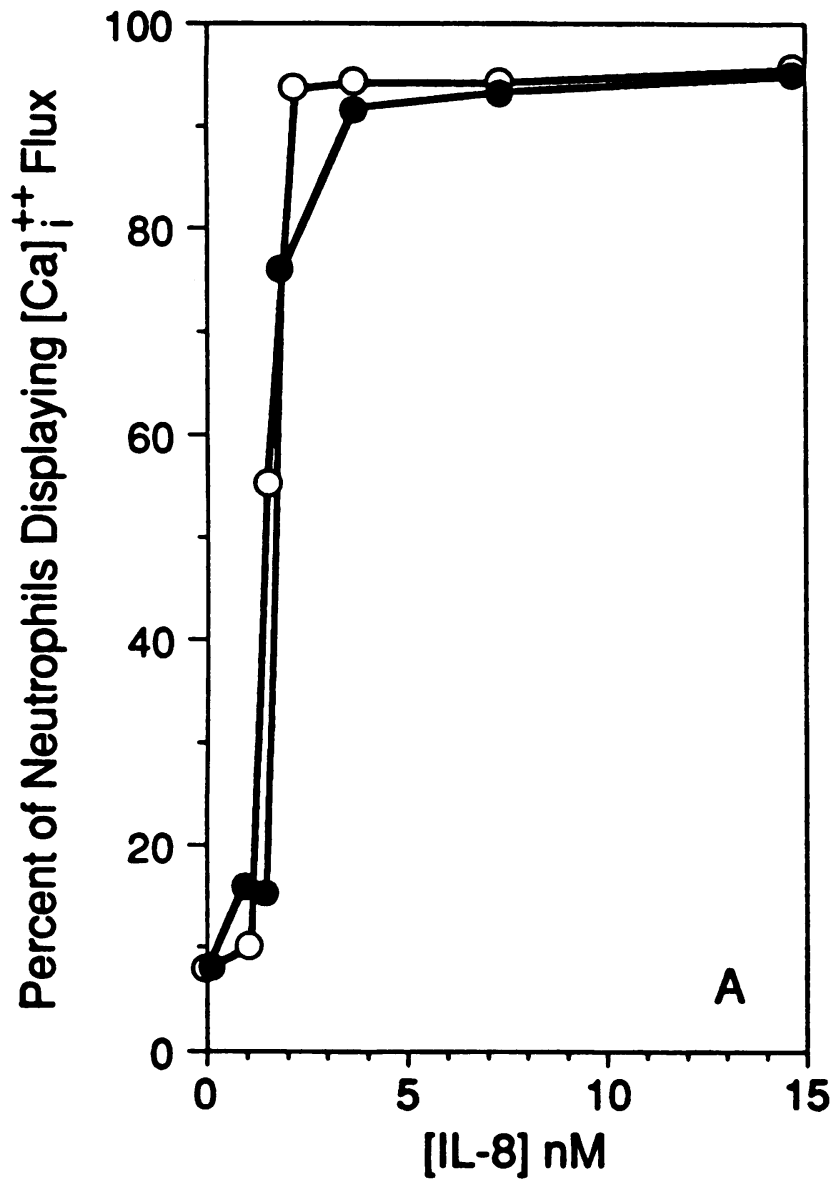

generated with both [ala-IL-8 $]_{77}$ and [ser-IL-8 $]_{72}$ forms of IL-8 were very steep, indicating little response below $\approx 1 \mathrm{nM}$ IL-8 and maximal response above $\approx 2$ nM IL-8 (Fig. 8, $A$ ). IL-8 at $10 \mathrm{pM}$ elicited little if any release of calcium ion (Fig. 8, $B$ ). Approximately half of the cell population mobilized calcium in response to $1.5 \mathrm{nM}$ IL-8 (Fig. 8, $C$ ), and this fraction approached $100 \%$ at $10 \mathrm{nM}$ IL-8 (Fig. 8, D).

To determine whether IL- 8 bound to red cells was accessible to neutrophils, red cells were loaded with IL- 8 by incubation with the polypeptide at concentrations from 0.1 to 100 nM. Unbound IL-8 was removed by sedimentation and resuspension of the cells in IL-8-free buffer. The cells were not diluted during the washing step, to prevent the loss of bound IL-8 that occurs on dilution (Fig. 3). (This wash procedure resulted in efficient retention of the bound IL-8, as indicated by a control experiment carried out with $10 \mathrm{nM}^{125} \mathrm{I}-\mathrm{IL}-8$. In this case $7.7 \mathrm{nM}^{125} \mathrm{I}-\mathrm{IL}-8$ became bound and $7.0 \mathrm{nM}{ }^{125} \mathrm{I}-\mathrm{IL}-8$ was retained by the red cells after the wash [data not shown]). The red cells were then mixed with indo-1-loaded neutrophils at a neutrophil/red cell ratio of $1: 100$. The cell mixtures were then immediately injected into the FACS, gating on the neutrophil population. As shown in Fig. 9, no detectable rise in neutrophil cytoplasmic free calcium occurred in these mixtures. This failure to respond to IL-8 was not caused by damage to the neutrophils or loss of sensitivity of the cells to IL-8, because excess (100 nM) IL-8 added to these mixtures triggered a rapid large scale increase in intracellular free calcium.

Monocyte chemotactic peptide-1 binding to red cells. Reasoning that red cells might serve as a sink for other chemotactic

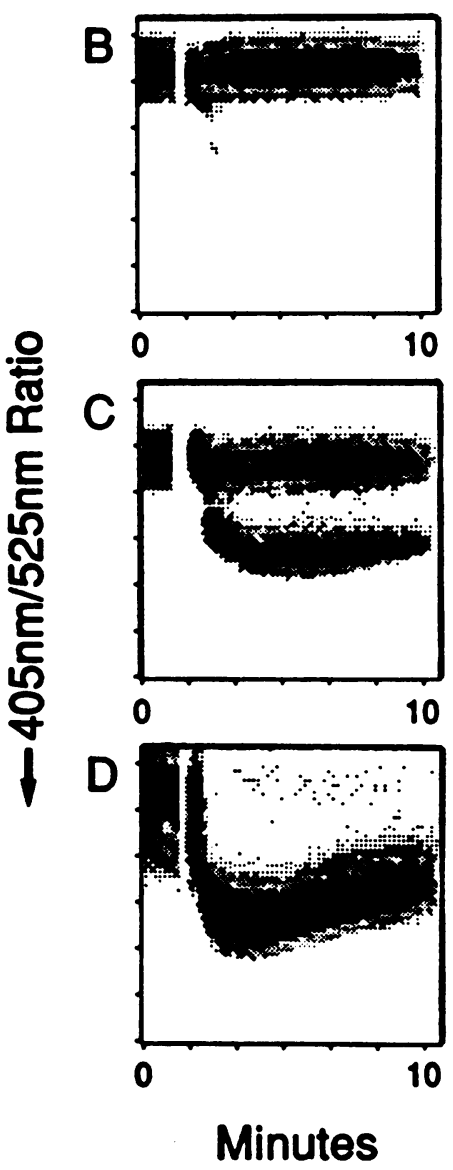

Figure 8. Flow cytometric analysis of $\mathrm{Ca}^{2+}$ mobilization in neutrophils stimulated with IL-8. $A$ shows the percentage of neutrophils responding (integrated at 2-4 min after addition of IL-8) as a function of IL-8 concentration. The dose-response curves for both [ala-IL-8] ${ }_{77}$ and [ser-IL$8]_{72}$ are shown (closed and open circles respectively). Representative bivariate histograms plotting the $405 / 525 \mathrm{~nm}$ fluorescence ratio against time are shown in $B$, $C$, and $D$. The cells were equilibrated and a baseline ratio established before the addition of either $10 \mathrm{pM}(B), 1.5 \mathrm{nM}(C)$, or $10 \mathrm{nM}(D)$ IL-8. Baseline ratio shown in each histogram before the break representing the time of IL-8 addition. This data is representative of several experiments where $\mathrm{Ca}^{2+}$ mobilization has been monitored to determine neutrophil activation. 


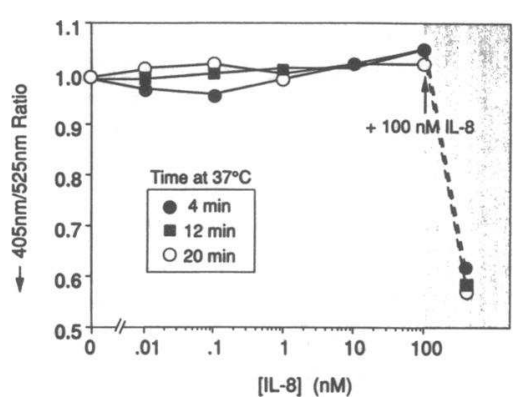

Figure 9. Measurement of free $\mathrm{Ca}^{2+}$ in neutrophils incubated with red cells that were preloaded with IL-8. Red cells at $4 \times 10^{9}$ cells $/ \mathrm{ml}$ in $0.5 \mathrm{ml}$ were preincubated with the indicated amounts of IL-8 for 4 , 12 , or $20 \mathrm{~min}$ at $37^{\circ} \mathrm{C}$. Unbound IL-8 was removed by two $250 \mu \mathrm{l}$

washes with $1 \%$ BSA/PBS. Neutrophils loaded with Indo-1 as described in Methods, were then mixed with the red cells at a neutrophil to red cell ratio of $1: 100$. The red cells were electronically gated out using a combination of forward angle light scatter, $90^{\circ}$ light scatter and Indo-1 fluorescence. Therefore, displayed is the Indo-1 response $(405 / 525 \mathrm{~nm}$ ratio) of the neutrophils only. At the arrow $100 \mathrm{nM}$ IL-8 was added to a subset of the neutrophil/IL-8-loaded red cell mixtures. This data is representative of two experiments.

cytokines, we have examined the interaction of red cells with monocyte chemotactic peptide-1 (MCP-1), a recently defined chemotaxin produced by vascular smooth muscle cells and cytokine-stimulated peripheral blood mononuclear leukocytes $(33,34) . M C P-1$ is a member of the same relatively large family of polypeptides that includes IL-8 $(34,35)$. Unlike IL-8, MCP1 does not have chemotactic activity for neutrophils (33).

Similar to the results with ${ }^{125} \mathrm{I}-\mathrm{IL}-8$, addition of $1 \mathrm{nM}{ }^{125} \mathrm{I}-$ MCP-1 (details of the purification and iodination of the native human polypeptide is described in reference 36 ) to purified red cells at $4 \times 10^{9}$ per $\mathrm{ml}$ resulted in $63 \%$ of the radiolabeled ligand becoming bound to the cells, and $70 \%$ of the binding was inhibited by a 100-fold excess of nonlabeled MCP-1 (data not shown). The total binding ( \pm SD) of $0.1,1$, and $5 \mathrm{nM}^{125} \mathrm{I}-\mathrm{MCP}$ $1(61,687 \pm 568,569,318 \pm 13,830$, and $2,161,235 \pm 45,232 \mathrm{CPM}$ respectively) to $7.4 \times 10^{8}$ red cells was inhibited to a similar

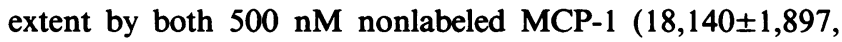
$194,351 \pm 8,989$, and $800,939 \pm 94,130 \mathrm{CPM}$ bound) and 500 nM nonlabeled IL-8 $(22,910 \pm 2178,194,656 \pm 10,259$, and $920,587 \pm 69,988$ CPM bound). These results suggest that both MCP-1 and IL-8 bind to the same receptor on the red cell surface.

\section{Discussion}

The major point of this paper is that red blood cells carry on their surfaces IL-8-binding proteins that significantly diminish the concentration of soluble IL-8 in blood plasma. The evidence for IL-8 extraction by red cells comes from examination of ${ }^{125}$ I-IL-8 binding, from FACS detections of FITC-IL-8 binding and native IL- 8 binding (determined using anti-IL- 8 antibody), and from examination of the influence of red cells on the diffusion of IL-8 across the compartments of diffusion chambers. The ${ }^{125} \mathrm{I}-\mathrm{IL}-8$ binding data indicate that this redistribution of IL-8 from plasma onto red cells is mediated by specific high affinity $\left(\approx 5 \mathrm{nM} K_{\mathrm{d}}\right)$ binding sites for IL-8 that are present on the red cell surface at $\approx 2,000$ sites per cell.

Although there are numerous examples of cytokine and hormone binding proteins in blood $(28,29)$, in general these are soluble plasma proteins. We know of no other case in which the red blood cell acts as a major sink for a signal-transmitting polypeptide. Red cells do bind insulin and insulin-like growth factors, but not so extensively as to substantially reduce the soluble levels of these hormones $(37,38,39)$. The red cell surface is also a key site for control of other proteins that play a role in inflammatory processes. The transmembrane protein $\mathrm{CR} 1$ is an essential cofactor for the cleavage of C3bi, and is also a carrier of immune complexes to the liver for clearance (40, 41). Decay accelerating factor, which is associated with the red cell membrane by a fatty acyl linkage, inhibits the assembly and accelerates the decay of $C 3$ convertase $(41,42)$.

These results, although novel, are generally consistent with the literature. In a recently reported screening study Besemer et al. (25) detected very little specific binding of ${ }^{125} \mathrm{I}-\mathrm{IL}-8$ to red cells, but in these experiments the number of red cells used in the binding incubations was less than $1 \%$ of the number used here. These investigators also noted that their study did not address the possibility that red cells might have IL-8 receptors with a $K_{d}>3 \mathrm{nM}$. Our results are also not inconsistent with the view that the neutrophil is a principal responsive target cell for IL-8. Previous studies show that neutrophils carry at least 30,000 IL-8 receptors per cell $(43,25)$. The 1,000 -fold greater abundance of red cells over neutrophils in blood accounts for our finding that red cells are responsible for the bulk of the binding of ${ }^{125} \mathrm{I}-\mathrm{IL}-8$ to cells in whole blood.

Our finding that IL-8 absorbed to red cells did not stimulate an increase in neutrophil free calcium suggests that red cells limit neutrophil interaction with IL-8 in the bloodstream. This function could be physiologically important, as endotoxin or inflammatory cytokines stimulate the accumulation of large amounts of IL- 8 by monocytes, T lymphocytes, and endothelial cells in whole blood (references 1, 4, and 44, W. C. Darbonne, unpublished data). Studies in which IL-8 has been injected intravenously indicate that even transiently existing, modest, intravascular levels of this chemotaxin/agonist inhibit targeting of neutrophils to sites of inflammation (17). Moreover, the activity of extravascularly administered or secreted IL-8 to induce leukocyte chemotaxis depends on the nature of IL-8 concentration gradients that develop across capillaries. Neutrophil responses to IL-8 occur within seconds and exhibit dose dependence over the $\sim 0.1-5 \mathrm{nM}$ range (8). Significantly, these results show that red cells bind IL-8 extraordinarily rapidly, and extract $>80 \%$ of soluble IL- 8 when the cytokine is added to blood in this concentration range. Binding and neutralization of IL- 8 by red cells may provide a line of defense against systemic activation and chemotactic disorientation of neutrophils.

Our results showing the competitive binding of IL-8 and MCP-1 to red cells suggests that red cells may act as a general intravascular sink for soluble chemotaxins. This effect could localize the activation of the respective target cell(s) at the site of the intravascular secretion, and/or properly orient the chemotaxin concentration gradient across the vascular wall. These findings should prompt an examination of the interactions of red cells with other polypeptides on the rapidly growing list of chemotactic cytokines.

\section{References}

1. Yoshimura, T., K. Matsushima, S. Tanaka, E. A. Robinson, E. Appella, J. J. Oppenheim, and E. J. Leonard. 1987. Purification of a human monocytederived neutrophil chemotactic factor that has peptide sequence similarity to other defense cytokines. Proc. Natl. Acad. Sci. USA. 84:9233-9237.

2. Schröder, J. M., U. Mrowietz, E. Morita, and E. Christophers. 1987. Purification and partial biochemical characterization of a human monocyte-derived, 
neutrophil-activating peptide that lacks interleukin-1 activity. J. Immunol. 139:3474-3483.

3. Walz, A., P. Peveri, H. Aschauer, and M. Baggiolini. 1987. Purification and amino acid sequencing of NAF, a novel neutrophil-activating factor produced by monocytes. Biochem. Biophys. Res. Commun. 149:755-761.

4. Gregory, H., J. Young, J. M. Schröder, U. Mrowietz, and E. Christophers 1988. Structure determination of a human lymphocyte derived neutrophil activating peptide (LYNAP). Biochem. Biophys. Res. Commun. 151:883-890.

5. Strieter, R. M., S. H. Phan, H. J. Schowell, D. G. Remick, J. P. Lynch, M Genord, C. Raiford, M. Eskandari, R. M. Marks, and S. L. Kunkel. 1989. Monokine-induced neutrophil chemotactic factor gene expression in human fibroblasts. J. Biol. Chem. 264:10621-10626.

6. Strieter, R. M., S. L. Kunkel, H. J. Schowell, and R. M. Marks. 1988. Monokine-induced gene expression of a human endothelial cell derived neutrophil chemotactic factor. Biochem. Biophys. Res. Commun. 156:1340-1345.

7. Schröder, J. M., and E. Christophers. 1989. Secretion of novel and homologous neutrophil-activating peptides by LPS-stimulated human endothelial cells. J. Immunol. 142:244-251.

8. Baggiolini, M., A. Walz, and S. L. Kunkel. 1989. Neutrophil-activating peptide-1/interleukin 8 , a novel cytokine that activates neutrophils. J. Clin. In vest. 84:1045-1049.

9. Larsen, C. G., A. O. Anderson, E. Appella, J. J. Oppenheim, and K. Matsushima. 1989. The Neutrophil Activating Peptide (NAP-1) is also chemotactic for T-lymphocytes. Science (Wash. DC) 243:1464-1466.

10. Peveri, P., A. Walz, B. Dewald, and M. Baggiolini. 1988. A novel neutrophil-activating factor produced by human mononuclear phagocytes. J. Exp. Med. 167:1547-1559.

11. Thelen, M., P. Peveri, P. Kernen, V. von Tschurner, A. Walz, and M. Baggiolini. 1988. Mechanism of neutrophil activation by NAF, a novel monocyte-derived peptide agonist. FASEB (Fed. Am. Soc. Exp. Biol.) J. 2:2702-2706.

12. Carveth, H. J., J. F. Bohnsack, T. M. McIntyre, M. Baggiolini, S. M. Prescott, and G. A. Zimmerman. 1989. Neutrophil activating factor (NAF) induces polymorphonuclear leukocyte adherence to endothelial cells and to subendothelial matrix proteins. Biochem. Biophys. Res. Commun. 162:387-393.

13. Detmers, P. A., S. K. Lo, E. Olsen-Egbert, A. Walz, M. Baggiolini, and Z. A. Cohn. 1990. Neutrophil-activating protein-1/interleukin 8 stimulates the binding activity of the leukocyte adhesion receptor CD11b/CD18 on human neutrophils. J. Exp. Med. 171:1155-1162.

14. Gimbrone, M. A., Jr., M. S. Obin, A. F. Brock, E. A. Luis, P. E. Hass, C. A Hébert, Y. K. Yip, D. W. Leung, D. G. Lowe, W. J. Kohr, W. C. Darbonne, K. B. Bechtol, and J. B. Baker. 1989. Endothelial interleukin 8: a novel inhibitor of leukocyte-endothelial interactions. Science (Wash. DC). 246:1601-1603.

15. Colditz, I., R. Zwahlen, B. Dewald, and M. Baggiolini. 1989. In vitro inflammatory activity of neutrophil activating factor, a novel chemotactic peptide derived from human monocytes. Am. J. Pathol. 134:755-760.

16. Van Damme, J., J. Van Beeumen, G. Oppendakker, and A. Billiau. 1988. A novel $\mathrm{NH}_{2}$ sequence-characterized human monokine possessing neutrophil chemotactic, skin-reactive, and granulocytosis-promoting activity. J. Exp. Med. 167:1364-1376.

17. Hechtman, D. H., M. I. Cybulsky, H. J. Fuchs, J. B. Baker, and M. A. Gimbrone, Jr. 1991. Intravascular IL8, inhibitor of polymorphonuclear leukocyte accumulation at sites of acute inflammation. J. Immunol. 147:883-892

18. Rot, A. 1991. Some aspects of NAP-1 pathophysiology: lung damage caused by a bloodborn cytokine. In Chemotactic Cytokines: Biology of the Inflammatory Peptide Supergene Family. J. Westwick, S. Kunkel, and I. J. D. Lindley, editors. Plenum Publishing Co., London. In press.

19. Hébert, C. A., F. W. Luscinskas, J. M. Kiely, E. A. Luis, W. C. Darbonne G. T. Bennett, C. C. Liu, M. S. Obin, M. A. Gimbrone, Jr., and J. B. Baker. 1990 Endothelial and leukocyte forms of interleukin 8: conversion by thrombin and interactions with neutrophils. J. Immunol. 145:3033-3040.

20. Ramakrishnan, V., D. V. Sinicropi, R. Dere, W. C. Darbonne, K. B. Bechtol, and J. B. Baker. 1990. Interaction of wild-type and catalytically inactive mutant forms of tissue-type plasminogen activator with human umbilical vein endothelial cell monolayers. J. Biol. Chem. 265:2755-2762.

21. Wheeler, M. E., F. W. Luscinskas, M. P. Bevilaqua, and M. A. Gimbrone 1988. Cultured human endothelial cells stimulated with cytokines or endotoxin produce an inhibitor of leukocyte adhesion. J. Clin. Invest. 82:1211-1218.
22. Nakao, M., T. Nakayama, and T. Kankura. 1973. A new method for separating human blood components. Nat. New Biol. 246:94.

23. Beutler, E., C. West, and K. G. Blume. 1976. The removal of leukocytes and platelets from whole blood. J. Lab. Clin. Med. 88:328-333.

24. Hanahan, D., and J. E. Ekholm. 1974. The preparation of red cell ghosts. Methods Enzymol. 31:168-172.

25. Besemer, J., A. Hujber, and B. Kuhn. 1989. Specific binding, internalization, and degradation of neutrophil activating factor by human polymorphonuclear leukocytes. J. Biol. Chem. 264:17409-17415.

26. Grynkiewicz, G., M. Poenie, and R. Y. Tsien. 1985. A new generation of $\mathrm{Ca} 2+$ indicators with greatly improved fluorescence properties. J. Biol. Chem. 260:3440-3450.

27. June, C. H., and P. S. Rabinovitch. 1988. Flow cytometric measurement of cellular ionized calcium concentration. Pathol. Immunopathol. Res. 7:409432.

28. Baumann, G., M. W. Stolar, and K. Anburn. 1986. A specific growth hormone binding protein in human plasma; initial characterization. J. Clin. Endocrinol. Metab. 62:134-141.

29. Drop, S. L. S., D. J. Kortleve, and H. Guyda. 1984. Isolation of a somatomedin-binding protein from preterm amniotic fluid. Development of a radioimmunoassay. J. Clin. Endocrinol. Metab. 59:899-907.

30. Munson, P., D. Rodbard. 1980. LIGAND, a versatile computerized approach for characterization of ligand-binding systems. Anal. Biochem. 107:220239.

31. Haigler, H. T., F. R. Maxfield, M. C. Willingham, and I. Pastan. 1980. Dansylcadaverine inhibits internalization of ${ }^{125} \mathrm{I}$-epidermal growth factor in BALB 3T3 cells. J. Biol. Chem. 255:1239-1241.

32. Bajpai, A., and J. B. Baker. 1985. Cryptic urokinase binding sites on human foreskin fibroblasts. Biochem. Biophys. Res. Commun. 133:475-482.

33. Valente, A. J., S. R. Fowler, E. A. Sprague, J. L. Kelley, C. A. Suenram, and C. J. Schwartz. 1984. Initial characterization of a peripheral blood mononuclear cell chemoattractant derived from cultured arterial smooth muscle cells. Am. J. Pathol. 117:409-417.

34. Yoshimura, T., N. Yuhki, S. K. Moore, E. Appella, M. I Lerman, and E. J. Leonard. 1989. Human monocyte chemoattractant protein-1 (MCP-1): full length cDNA cloning, expression in mitogen-stimulated blood mononuclear leukocytes, and sequence similarity to mouse competence gene JE. FEBS (Fed. Eur. Biol. Soc.) Lett. 244:487-493.

35. Wolpe, S. D., and A. Cerami. 1989. Macrophage inflammatory proteins 1 and 2: members of a novel superfamily of cytokines. FASEB (Fed. Am. Soc. Exp. Biol.) J. 3:2565-2573.

36. Valente, A. J., M. M. Rozek, D. T. Graves and C. J. Schwartz. 1991. Characterization of monocyte chemotactic protein-1 (MCP-1) binding to human monocytes. Biochem. Biophys. Res. Commun. 176:309-314.

37. Gambhir, K. K., J. A. Archer, and C. J. Bradley. 1978. Characteristics of human erythrocyte insulin receptors. Diabetes. 27:701-708.

38. Marttinen, A. 1986. Dependence of insulin degradation by intact erythrocytes on receptor binding in diabetic patients. Exp. Clin. Endocrinol. 88:71-75.

39. Polychronakos, C., H. J. Guyda, and B. I. Posner. 1983. Receptors for the insulin-like growth factors on human erythrocytes. J. Clin. Endocrinol. Metab. $57: 436-438$.

40. Jida, K., and V. Nussenzweig. 1983. Functional properties of membrane associated complement receptor CR1. J. Immunol. 130:1876-1880.

41. Muller-Eberhard, H. J. 1988. Complement: chemistry and pathways. In Inflammation: Basic Principles and Clinical Correlates. J. I. Gallin, I. M. Goldstein, and R. Snyderman, editors. Raven Press Ltd., New York. 21-53.

42. Nicholson-Weller, A., J. Burge, D. T. Fearon, P. F. Weller, and K. F. Austen. 1982. Isolation of a human erythrocyte membrane glycoprotein with decay accelerating activity for $\mathrm{C} 3$ convertases of the complement system. J. Immunol. 129:184-189.

43. Samanta, A. K., J. J. Oppenheim, and K. Matsushima. 1989. Identification and characterization of specific receptors for monocyte-derived neutrophil chemotactic factor (MDNCF) on human neutrophils. J. Exp. Med. 169:11851189.

44. Ham, J. M., R. M. Strieter, J. Westwick, D. A. Campbell, and S. L. Kunkel. 1990. Chemotactic cytokine gene expression in human whole blood. FASAB (Fed. Am. Soc. Exp. Biol.) J. 4:A1236. (Abstr.) 